This is a postprint version of the following published document:

González-Sánchez. M.I., et al. Electrochemical detection of extracellular hydrogen peroxide in Arabidopsis thaliana: a real-time marker of oxidative stress. In: Plant, cell \& environment, 36(4), April 2013, Pp. 869-878

DOI: https://doi.org/10.1111/pce.12023

(C) 2012 Blackwell Publishing Ltd. 


\title{
Electrochemical detection of extracellular hydrogen peroxide in Arabidopsis thaliana: a real-time marker of oxidative stress
}

\author{
M. I. GONZÁLEZ-SÁNCHEZ ${ }^{1}$, L. GONZÁLEZ-MACIA², M. T. PÉREZ-PRIOR ${ }^{1}$, E. VALERO ${ }^{1}$, J. HANCOCK² \& \\ A. J. KILLARD ${ }^{2}$
}

${ }^{1}$ Departamento de Química-Física, Escuela de Ingenieros Industriales, Universidad de Castilla-La Mancha, Campus Universitario, 02071 Albacete, Spain and ${ }^{2}$ Department of Applied Sciences, University of the West England, Coldharbour Lane, Bristol BS16 1QY, UK

\begin{abstract}
An electrochemical approach to directly measure the dynamic process of $\mathrm{H}_{2} \mathrm{O}_{2}$ release from cultures of Arabidopsis thaliana cells is reported. This approach is based on $\mathrm{H}_{2} \mathrm{O}_{2}$ oxidation on a $\mathrm{Pt}$ electrode in conjunction with continuous measurement of sample pH. For $\left[\mathrm{H}_{2} \mathrm{O}_{2}\right]<\mathbf{1 ~ m M}$, calibration plots were linear and the amperometric response of the electrode was maximum at $\mathrm{pH}$ 6. At higher concentrations $\left(\left[\mathrm{H}_{2} \mathrm{O}_{2}\right]>1 \mathrm{mM}\right)$, the amperometric response can be described by Michaelian-type kinetics and a mathematical expression relating current intensity and $\mathrm{pH}$ was obtained to quantitatively determine $\mathrm{H}_{2} \mathrm{O}_{2}$ concentration. At pH 5.5, the detection limit of the sensor was $3.1 \mu \mathrm{M}(\mathrm{S} / \mathrm{N}=3)$, with a response sensitivity of $0.16 \mathrm{AM}^{-1} \mathrm{~cm}^{-2}$ and reproducibility was within $6.1 \%$ in the range $1-5 \times 10^{-3} M(n=5)$. Cell suspensions under normal physiological conditions had a pH between 5.5-5.7 and $\mathrm{H}_{2} \mathrm{O}_{2}$ concentrations in the range 7.0$20.5 \mu \mathrm{M}(n=5)$. The addition of exogenous $\mathrm{H}_{2} \mathrm{O}_{2}$, as well as other potential stress stimuli, was made to the cells and the change in $\mathrm{H}_{2} \mathrm{O}_{2}$ concentration was monitored. This real-time quantitative $\mathrm{H}_{2} \mathrm{O}_{2}$ analysis is a potential marker for the evaluation of oxidative stress in plant cell cultures.
\end{abstract}

Key-words: amperometric sensor; plant cells; Pt electrode.

\section{INTRODUCTION}

In plants, even under optimal conditions, many metabolic processes, including chloroplastic, mitochondrial and plasma membrane-linked electron transport systems, produce reactive oxygen species (ROS) such as the superoxide radical $\left(\mathrm{O}_{2}^{--}\right)$, hydrogen peroxide $\left(\mathrm{H}_{2} \mathrm{O}_{2}\right)$ and the hydroxyl free radical $\left(\mathrm{HO}^{\circ}\right)$. Among these, $\mathrm{H}_{2} \mathrm{O}_{2}$ is the most commonly studied in cellular environments due to its stability and penetrability through cellular membranes (Wu et al.2011a). It is an important, naturally occurring ROS that has been gaining recognition in biological sciences as a subcellular signalling molecule (Rhee 2006).

Intra- and intercellular levels of $\mathrm{H}_{2} \mathrm{O}_{2}$ increase during environmental stresses such as intense light, temperature,

Correspondence: M. I. González-Sánchez. E-mail: MIsabel. gonzalez@uclm.es desiccation, salt, heavy metal contamination, air pollutants, herbicides, etc. Its accumulation can lead to oxidative stress, characterized by disruption of cellular homeostasis, which triggers cell death. However, $\mathrm{H}_{2} \mathrm{O}_{2}$ not only leads to cellular damage, but it has also been shown to induce a defensive response during both biotic and abiotic stresses at moderately elevated levels (Dat et al. 2000). Thus, a fine-tuned balance between $\mathrm{H}_{2} \mathrm{O}_{2}$ production and its removal is crucial for plant cell survival. Major $\mathrm{H}_{2} \mathrm{O}_{2}$-scavenging enzymes of plants include ascorbate peroxidase, catalase, glutathione peroxidase and peroxiredoxin, that together with antioxidant compounds, provide cells with highly efficient machinery for detoxifying $\mathrm{H}_{2} \mathrm{O}_{2}$ (Mittler et al. 2004). In addition, this detoxification is also carried out by the glutathione-ascorbate (GHS-ASC) cycle, which is a complex network of spontaneous, photochemical and enzymatic reactions (Noctor \& Foyer 1998; Valero et al. 2009). Bearing in mind the great importance of $\mathrm{H}_{2} \mathrm{O}_{2}$ in living organisms, accurate and sensitive analytical methods to quantify this metabolite are required. Traditionally, $\mathrm{H}_{2} \mathrm{O}_{2}$ has been detected using several analytical techniques, such as titrimetry (Hurdis \& Romeyn 1954), spectrophotometry (Gay, Collins \& Gebicki 1999) and chemiluminiscence (Hanaoka, Lin \& Yamada 2001). However, these approaches are based on indirect methods that have been shown to be time consuming, difficult to automate and highly prone to interferences. Furthermore, dyes are also widely used to determine $\mathrm{H}_{2} \mathrm{O}_{2}$ (Rhee et al. 2010) although there are some issues and concerns around their use. VeljovicJovanonic, Noctor \& Foyer (2002) and Queval et al. (2008) have very clearly discussed some of the difficulties in accurately measuring $\mathrm{H}_{2} \mathrm{O}_{2}$ in leaf extracts.

Recently, electrochemical methods have become the techniques of choice because of their low cost, excellent analytical characteristics, simple operation and speed of use (Guascito et al. 2008). Among these methods, amperometric techniques have increasingly become more attractive in biological applications because they possess excellent temporal resolution, allowing information about the production and consumption of $\mathrm{H}_{2} \mathrm{O}_{2}$ in real time (Amatore et al.2008). Most amperometric techniques rely on enzyme-based biosensors that usually depend on the enzymatic reduction of $\mathrm{H}_{2} \mathrm{O}_{2}$ using peroxidases (Wu et al. 2011b) or haemoglobin (Wei et al.2011). One drawback of these biological sensors is a lack of stability originating mainly from the $\mathrm{H}_{2} \mathrm{O}_{2}$-induced suicide 
inactivation of the protein (González-Sánchez et al. 2011a,b) and the special requirements of temperature, concentration and $\mathrm{pH}$. To solve these problems, considerable attention has been paid to developing non-enzymatic electrodes. Many metals such as Pt (Zhang \& Wilson 1993), Ag (Flätgen et al. 1999) and Pd (Cao et al. 2008) have been employed as catalysts for $\mathrm{H}_{2} \mathrm{O}_{2}$ reactions. Recently, the enhanced electrochemical reduction of $\mathrm{H}_{2} \mathrm{O}_{2}$ at $\mathrm{Ag}$ electrodes modified with surfactants and salt has been reported as a very promising tool in the development of new non-enzymatic sensors (González-Macia et al. 2011).

A sensor - particularly one that is developed for the purpose of long-term in vivo measurements - requires that the sensor material be robust. $\mathrm{Pt}$ is certainly one of the best choices because of its physical stability, inertness and the excellent reproducibility of its redox potentials (Zhang \& Wilson 1993). For all these advantages, the Pt electrode was selected here to directly quantify the extracellular $\mathrm{H}_{2} \mathrm{O}_{2}$ in plant cell suspensions. Xu et al. (2010) reported an electrochemical method using poly-o-phenylenediamine and a $\mathrm{Pt}$ microparticle-modified $\mathrm{Pt}$ electrode as a sensor for the in vivo detection of oxidative burst induced by $\mathrm{Cd}^{2+}$ stress in oilseed rape. However, a detailed $\mathrm{pH}$-dependent quantitative analysis was not performed.

Therefore, our main goal was to use a simple, rapid, direct and sensitive electrochemical method based on a Pt electrode for the quantitative determination of $\mathrm{H}_{2} \mathrm{O}_{2}$ in plant cell suspensions using Arabidopsis thaliana as a model system. This main objective was addressed as follows: (1) to measure the concentration of extracellular $\mathrm{H}_{2} \mathrm{O}_{2}$ in A. thaliana cell suspensions under normal physiological conditions; (2) to evaluate the response of cells against exogenously added $\mathrm{H}_{2} \mathrm{O}_{2}$ and (3) to quantify the endogenous $\mathrm{H}_{2} \mathrm{O}_{2}$ produced while cells are subjected to different stress conditions. This evaluation of $\mathrm{H}_{2} \mathrm{O}_{2}$ content in the plant extracellular media can be an important oxidative burst marker in plant cell cultures.

\section{MATERIALS AND METHODS}

\section{Chemical and buffers}

Hydrogen peroxide, Murashige and Skoog Basal Medium, sucrose, 1-naphthaleneacetic acid, kinetin (4-(2hydroxyethyl)-1-piperazineethanesulfonic acid) (HEPES), ethylendiamino-tetraacetic acid (EDTA), sodium dodecyl sulfate (SDS), Triton X-100, protease inhibitor cocktail (for plant cells and tissue extracts, DMSO solution), albumin from bovine serum, Bradford reagent, catalase from bovine liver (2150 units per $\mathrm{mg}$ protein), horseradish peroxidase (167 units per mg protein), superoxide dismutase (3780 units per mg protein) from bovine erythrocytes, polygalacturonic acid, 3-amino-1,2,4-triazole and sulphates (aluminium, copper, ferrous, cadmium, zinc) were obtained from Sigma Aldrich (UK). A commercial insecticide containing thiacloprid as active component $\left(0.15 \mathrm{~g} \mathrm{~L}^{-1}\right)$ and a fertilizer (composition: $10.6 \% \mathrm{~N}, 4.4 \%$ total $\mathrm{P}_{2} \mathrm{O}_{5}, 1.9 \% \mathrm{P}, 1.7 \% \mathrm{~K}_{2} \mathrm{O}, 1.4 \%$ $\mathrm{K})$ were purchased locally.

\section{A. thaliana cell cultures}

Cell suspension cultures of $A$. thaliana were maintained as previously described (Clark et al. 2000). Cells were subcultured by transferring $5 \mathrm{~mL}$ of a 10-day-old culture into $100 \mathrm{~mL}$ of fresh AT3 medium (Murashige and Skoog medium supplemented with $3 \%(\mathrm{w} / \mathrm{v})$ sucrose, $0.5 \mathrm{mg} \mathrm{L}^{-1}$ 1-naphthaleneacetic acid and $0.05 \mathrm{mg} \mathrm{L}^{-1}$ kinetin, $\mathrm{pH} 5.5$ ). Cell cultures were incubated at $20^{\circ} \mathrm{C}$ on a rotary shaker under 16/8 h light/dark regime. For the experiments, 7-dayold $A$. thaliana cell suspensions were used. The cell density was determined microscopically using a counting chamber.

To determine total protein content in cell suspensions, cultures were frozen in liquid nitrogen, then ground in a mortar and pestle in extraction buffer. The extraction buffer consisted of 20 mm HEPES (pH 7.7), 1 mm EDTA, 0.4\% (w/v) SDS, $0.2 \%$ Triton X-100 and a complete protease inhibitor cocktail (Sigma Aldrich). The homogenate was centrifuged at $12000 \mathrm{~g}$ for $20 \mathrm{~min}$, the supernatant removed and frozen in liquid nitrogen. All the samples were stored at $-80{ }^{\circ} \mathrm{C}$ and protein concentrations were determined using the Bradford assay (Bradford 1976).

\section{Electrochemical apparatus}

Electrochemical measurements were carried out in aerobic conditions using an Autolab potentiostat Model PGSTAT302 N (Eco Chemie b.V., Utrecht, the Netherlands). The system was run by $\mathrm{PC}$ via the General Purpose Electrochemical System software for Windows, version NOVA (Eco Chemie b.V.). All electrochemical measurements were performed in a three-electrode system with a Pt electrode as working electrode, an $\mathrm{Ag} / \mathrm{AgCl}(3 \mathrm{M} \mathrm{KCl})$ electrode as reference and a $\mathrm{Pt}$ mesh as counter electrode. The $\mathrm{pH}$ was controlled with a Hanna Instruments HI 9321 Microprocessor pH-meter (Hanna Instruments Ltd, Bedforshire, UK).

\section{Electrochemical measurements}

The Pt working electrode was polished with 0.3 and $0.05 \mu \mathrm{m}$ alumina slurry paste and any residual abrasive particles were removed by subsequent sonication in $70 \%(\mathrm{v} / \mathrm{v})$ ethanol and water. The electroactive area of the working electrode used here was $0.0163 \mathrm{~cm}^{2}$, obtained from Randles-Sevcik relationship. It was calculated by cyclic voltammetry using $2.25 \mathrm{~mm}$ ferricyanide in $0.1 \mathrm{M} \mathrm{KCl}$ at different scan rates.

For electrochemical measurements of $A$. thaliana, $10 \mathrm{~mL}$ of cell suspension culture without any treatment were placed in the electrochemical cell. The cell suspension culture was stirred slowly and continuously. Electrochemical detection of $\mathrm{H}_{2} \mathrm{O}_{2}$ was performed by chronoamperometry, recording the current under a constant potential of $+0.6 \mathrm{~V}$ versus $\mathrm{Ag} / \mathrm{AgCl}$. The continuous monitoring of $\mathrm{pH}$ was performed in all the measurements.

\section{Calibration of the $\mathrm{H}_{2} \mathrm{O}_{2}$ sensor}

Calibration plots were made by successive additions of small volumes of the standard aqueous $\mathrm{H}_{2} \mathrm{O}_{2}$ solutions (stock 
solutions prepared daily) to stirred AT3 medium at the indicated concentrations, recording the current under a constant potential of $+0.6 \mathrm{~V}$. The usage of AT3 medium has been made to minimize possible interferences which its components could exert on the current signal. The $\mathrm{pH}$ was adjusted using $\mathrm{NaOH}$ or $\mathrm{HCl}$. Continuous monitoring of $\mathrm{pH}$ during calibration was performed and no appreciable variations were observed after the $\mathrm{H}_{2} \mathrm{O}_{2}$ additions.

\section{RESULTS AND DISCUSSION}

\section{$\mathrm{H}_{2} \mathrm{O}_{2}$ oxidation at the Pt electrode}

It is well known that $\mathrm{Pt}$ is able to catalyse the electrochemical oxidation of $\mathrm{H}_{2} \mathrm{O}_{2}$, which is a two-electron irreversible process involving both kinetic and mass transfer components (Zhang \& Wilson 1993). The Pt electrocatalytic characteristics for the oxidation of $\mathrm{H}_{2} \mathrm{O}_{2}$ in AT3 medium were evaluated at $\mathrm{pH}$ 5.5. Figure 1 shows the cyclic voltammograms obtained when the Pt electrode was introduced into AT3, both in the absence and presence of $\mathrm{H}_{2} \mathrm{O}_{2}$. It can be seen that the AT3 medium did not exhibit the presence of any interfering redox process (curve $b$ ). The addition of $\mathrm{H}_{2} \mathrm{O}_{2}$ (curves $c$ and $d$ ) gave rise to an anodic response on the bare Pt electrode at potentials greater than $+0.4 \mathrm{~V}$, which resulted from the oxidation of $\mathrm{H}_{2} \mathrm{O}_{2}$ versus $\mathrm{Ag} / \mathrm{AgCl}$ in AT3 as indicated in Eqn 1:

$$
\mathrm{H}_{2} \mathrm{O}_{2} \stackrel{\mathrm{Pt}}{\longrightarrow} \mathrm{O}_{2}+2 \mathrm{H}^{+}+2 \mathrm{e}^{-}
$$

In addition, a cathodic peak between 0 and $0.2 \mathrm{~V}$ was also observed in curves $b, c$ and $d$. This peak is associated with the reduction of $\mathrm{O}_{2}$ on the $\mathrm{Pt}$ electrode, as it was absent in cyclic voltammograms performed under anoxic conditions (curve

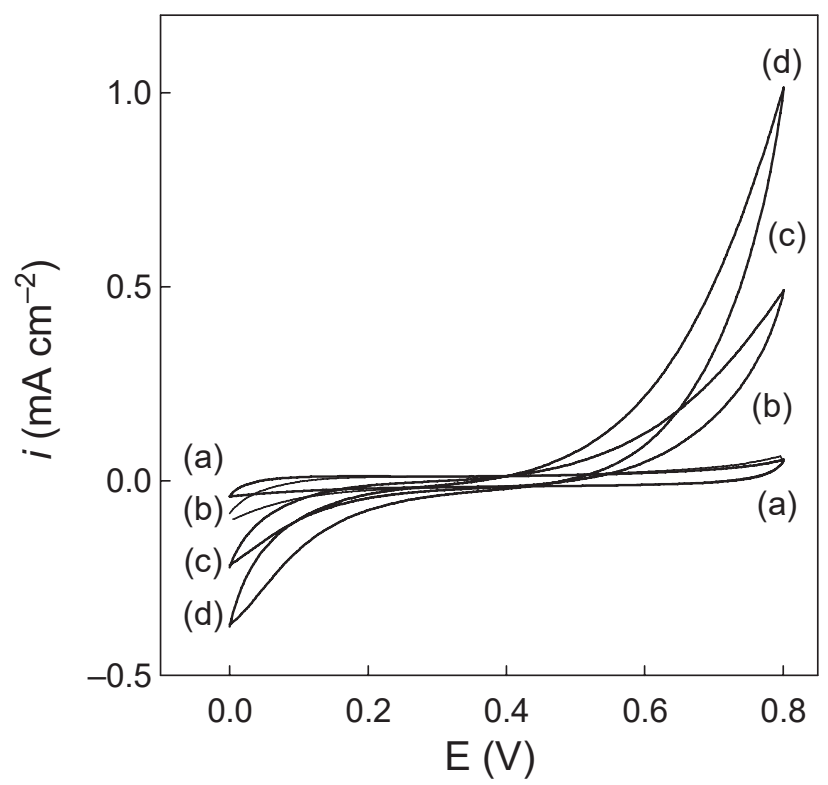

Figure 1. Cyclic voltammograms of the bare Pt electrode at pH 5.5: (a) AT3 deaerated in argon for $10 \mathrm{~min}$; (b) AT3; (c) AT3 containing $2 \mathrm{~mm} \mathrm{H}_{2} \mathrm{O}_{2}$ and (d) AT3 containing $5 \mathrm{~mm} \mathrm{H}_{2} \mathrm{O}_{2}$. a). This peak increased with $\mathrm{H}_{2} \mathrm{O}_{2}$ concentration (curves $c$ and $d$ ) as a consequence of the spontaneous partial decomposition of $\mathrm{H}_{2} \mathrm{O}_{2}$.

\section{Calibration of the Pt sensor at different $\mathrm{pH}$ values}

The Pt electrode was applied to the measurement of extracellular $\mathrm{H}_{2} \mathrm{O}_{2}$ concentrations in $A$. thaliana cell culture suspensions. In cells, unlike the symplast, which is relatively well buffered, homeostasis in the apoplast and extracellular medium is easily perturbed by stimuli or stresses (Pignocchi \& Foyer 2003). Extracellular alkalinization has been reported as one of the earliest responses against oxidative burst (Bolwell et al. 2002), as a result of the chemical processes on the outer surface of the plasmalemma (Pignocchi \& Foyer 2003). Therefore, a possible pH change in the extracellular medium in cell suspensions has to be expected. To avoid this, $\mathrm{pH}$ change ionophores and strong buffers could be used. However, these substantially inhibit the oxidative burst (Bolwell et al.2002), modifying the amount of $\mathrm{H}_{2} \mathrm{O}_{2}$ released by cells. To prevent this effect, measurements in cell suspensions should be made without any $\mathrm{pH}$ adjustment. As protons are involved in the $\mathrm{H}_{2} \mathrm{O}_{2}$ oxidation reaction by the Pt electrode (Eqn 1), there is a strong dependence of both potential and current on the $\mathrm{pH}$ of the solution (Zhang \& Wilson 1993). Therefore, calibration plots at different $\mathrm{pH}$ values should be performed.

Previous studies have showed that when $\mathrm{H}_{2} \mathrm{O}_{2}$ concentration is low $(<1 \mathrm{~mm})$, the reaction indicated in Eqn 1 is the predominant process at the electrode surface (Zhang \& Wilson 1993). The situation changes as the $\mathrm{H}_{2} \mathrm{O}_{2}$ concentration increases $(>1 \mathrm{~mm})$, since the decomposition of $\mathrm{H}_{2} \mathrm{O}_{2}$ is significant and the surface adsorption of either $\mathrm{H}_{2} \mathrm{O}_{2}$ or $\mathrm{O}_{2}$ leads to saturation. Our results (vide infra) showed a current response with different behaviour depending on the $\mathrm{H}_{2} \mathrm{O}_{2}$ concentration range studied. Therefore, different calibration plots were constructed for low and high $\mathrm{H}_{2} \mathrm{O}_{2}$ concentrations at different $\mathrm{pH}$ values to allow the quantitative analysis of $\mathrm{H}_{2} \mathrm{O}_{2}$.

\section{Calibration of the Pt sensor at low $\mathrm{H}_{2} \mathrm{O}_{2}$ concentrations $(<1 \mathrm{~mm})$}

The application of the Pt sensor in AT3 medium for the direct detection of $\mathrm{H}_{2} \mathrm{O}_{2}$ at low concentrations was assessed. The $\mathrm{H}_{2} \mathrm{O}_{2}$ concentration-dependent current at different $\mathrm{pHs}$ (in the range of 5 to 7 ) for $\left[\mathrm{H}_{2} \mathrm{O}_{2}\right]<1 \mathrm{~mm}$ is shown in Fig. 2a. The relationship between $\mathrm{H}_{2} \mathrm{O}_{2}$ concentration and current showed a linear dependence at any $\mathrm{pH}$, but with different response sensitivity. Sensitivity values could be calculated from the slope of the linear plots at the different $\mathrm{pH}$ values tested $\left(R^{2}=0.9976\right.$ to 0.9996$)$. The data obtained can be seen in Fig. 2b. The maximum sensitivity was obtained at $\mathrm{pH}$ 6.0. These results allow the calculation of $\mathrm{H}_{2} \mathrm{O}_{2}$ concentration at low levels at a known $\mathrm{pH}$, directly from amperometric data by interpolating into the response profile from Fig. 2b. For 

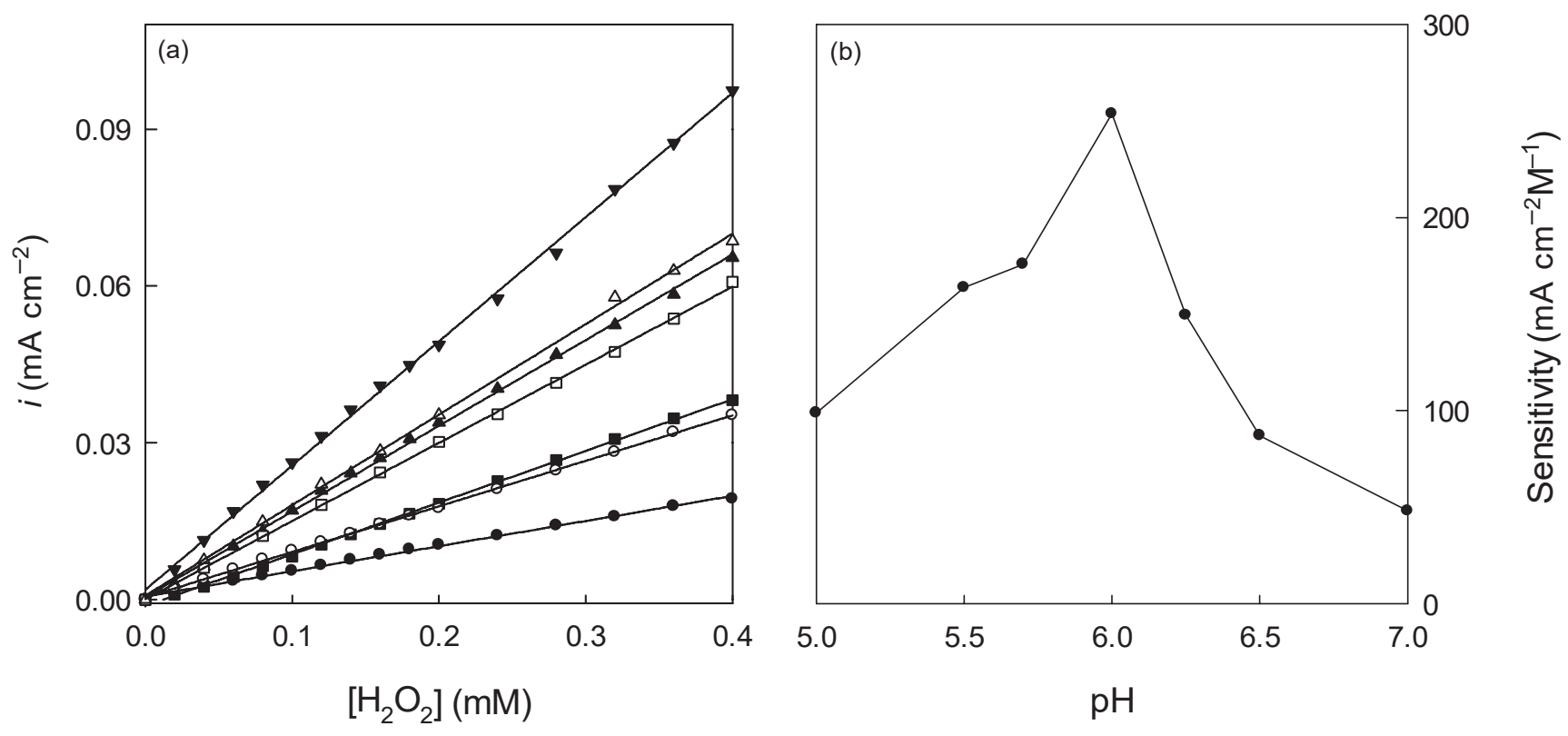

Figure 2. (a) Amperometric response of the Pt electrode in stirred $\mathrm{AT} 3$ at low $\mathrm{H}_{2} \mathrm{O}_{2}$ concentrations $(+0.6 \mathrm{~V}$ versus $\mathrm{Ag} / \mathrm{AgCl})$ at different pH values: $5.00(\square), 5.50(\mathbf{\Delta}), 5.75(\triangle), 6.00(\boldsymbol{\nabla}), 6.25(\square), 6.50(\bigcirc)$ and $7.00(\bullet)$. (b) Dependence of sensitivity to $\mathrm{pH}$.

example, at $\mathrm{pH} 5.5$, the detection limit was $3.1 \mu \mathrm{m}(\mathrm{S} / \mathrm{N}=3)$ and the sensitivity was $0.16 \mathrm{Am}^{-1} \mathrm{~cm}^{-2}$.

\section{Calibration of the Pt sensor at high $\mathrm{H}_{2} \mathrm{O}_{2}$ concentrations (>1 $\mathrm{mm})$}

The $\mathrm{H}_{2} \mathrm{O}_{2}$ concentration-dependent current at $\mathrm{pH}$ from 5 to 7 was also studied in AT3 medium for $\left[\mathrm{H}_{2} \mathrm{O}_{2}\right]>1 \mathrm{~mm}$ (Fig. 3a). As can be seen, in the range of concentrations here studied, the amperometric response increased as the $\mathrm{pH}$ was increased, which is in agreement with the results obtained by other authors (Zhang \& Wilson 1993). When comparing these data with calibration plots obtained at lower $\mathrm{H}_{2} \mathrm{O}_{2}$ concentrations, it can be seen that current response shows a different relationship to $\mathrm{pH}$, since at low concentrations, sensitivity peaks at approximately $\mathrm{pH} 6$, whereas at high concentrations, sensitivity increased across the range of $\mathrm{pH}$ from 5 to 7. This fact may be due to the different kinetic mechanism of $\mathrm{H}_{2} \mathrm{O}_{2}$ oxidation at the bare $\mathrm{Pt}$ electrode depending on the $\mathrm{H}_{2} \mathrm{O}_{2}$ concentration range under study. Reproducibility obtained was within $6.1 \%$ in the range $1-5 \times 10^{-3} \mathrm{M}(\mathrm{pH}=5.5$, $n=5$ ).

In addition, a deviation from linearity was observed at $\left[\mathrm{H}_{2} \mathrm{O}_{2}\right]>1 \mathrm{~mm}$ at all $\mathrm{pH}$ values studied (Fig. 3a). Hall, Khudaish \& Hart (1998) reported that the current response due to $\mathrm{H}_{2} \mathrm{O}_{2}$ oxidation is under mixed kinetic and diffusion control and that the mechanism for the oxidation of $\mathrm{H}_{2} \mathrm{O}_{2}$ can be explained in terms of Michaelian-type kinetics. Therefore, data from Fig. 3a were fitted to the hyperbolic-type equation (Eqn 2):

$i=\frac{a\left[\mathrm{H}_{2} \mathrm{O}_{2}\right]}{b+\left[\mathrm{H}_{2} \mathrm{O}_{2}\right]}$ and very good regression coefficients were thus obtained $\left(R^{2}=0.9894\right.$ to 0.9931$)$. To obtain an expression relating the current signal $(i), \mathrm{H}_{2} \mathrm{O}_{2}$ concentration and $\mathrm{pH}$, the coefficients $a$ and $b$ were plotted as a function of $\mathrm{pH}$ (Fig. 3b). These data were fitted by non-linear regression analysis to different equations and the best statistical results were obtained for a second-order polynomial and a uniexponential decay equation, respectively, as follows:

$a=a_{0}+a_{1} \mathrm{pH}+a_{2} \mathrm{pH}^{2}$

$b=b_{0}+b_{1} \mathrm{e}^{-b_{2} \mathrm{pH}}$

where $a_{0}, a_{1}, a_{2}, b_{0}, b_{1}$ and $b_{2}$ are the parameters obtained from the statistical analysis (Table 1 ), obtaining $R^{2}$ values of 0.9848 and 0.9930 for Eqns 3 and 4, respectively.

Inserting Eqns 3 and 4 into Eqn 2 and solving for $\left[\mathrm{H}_{2} \mathrm{O}_{2}\right]$, the mathematical expression in Eqn 5 was obtained, which allows the quantification of $\mathrm{H}_{2} \mathrm{O}_{2}$ concentrations once the current $(i)$ and the extracellular $\mathrm{pH}$ are known:

$\left[\mathrm{H}_{2} \mathrm{O}_{2}\right]=\frac{\left(b_{0}+b_{1} \exp \left(-b_{2} \mathrm{pH}\right)\right) i}{-i+a_{0}+a_{1} \mathrm{pH}+a_{2} \mathrm{pH}^{2}}$

The simultaneous measurement of $\mathrm{pH}$ and $i$ is possible with a normal potentiostat since most of them offer the possibility to include the integration of a $\mathrm{pH}$ electrode.

\section{The selectivity and interference characteristics}

The apoplast matrix of cells contains many enzymatic and non-enzymatic components, including solutes, proteins and 

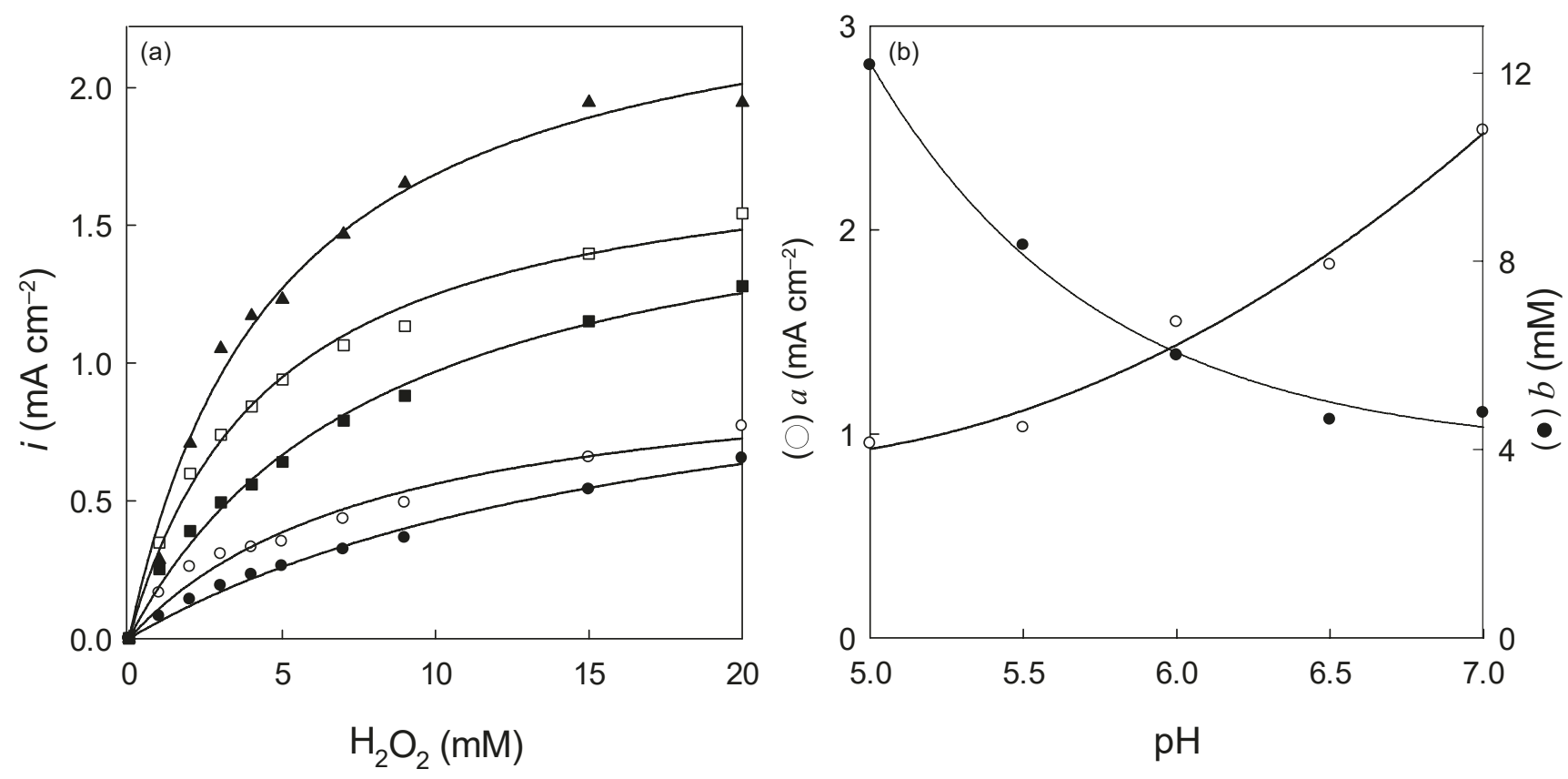

Figure 3. (a) Amperometric response of the Pt sensor in stirred AT3 at $\mathrm{H}_{2} \mathrm{O}_{2}>1 \mathrm{~mm}$ at different pH values: $5.0(\bullet), 5.5(\bigcirc), 6.0(\square), 6.5$ $(\square)$ and $7.0(\mathbf{\Delta})(+0.6 \mathrm{~V}$ versus $\mathrm{Ag} / \mathrm{AgCl})$. The points correspond to experimental data while the lines correspond to data obtained by non-linear regression analysis to Eqn 2. (b) Dependence of parameters $a(\bigcirc)$ and $b(\bullet)$ from Eqn 2 upon pH. The points correspond to parameters $a$ and $b$ obtained from Eqn 2 while the lines correspond to data obtained by non-linear regression analysis to Eqns 3 and 4 , respectively.

cell wall constituents (Pignocchi \& Foyer 2003). In order to better test the applicability of this electrochemical sensor, interferences from some substances that could usually be found in the apoplast and secreted into the culture medium were examined by amperometry. These were glucose $(100 \mu \mathrm{M})$, urea $(100 \mu \mathrm{m})$, mannitol $(100 \mu \mathrm{M})$, citric acid $(100 \mu \mathrm{M})$, dehydroascorbic acid $(100 \mu \mathrm{M})$, quercetin $(20 \mu \mathrm{M})$, catalase $\left(25 \mu \mathrm{g} \mathrm{mL}^{-1}\right)$, peroxidase $\left(25 \mu \mathrm{g} \mathrm{mL}^{-1}\right)$ and superoxide dismutase $\left(10 \mu \mathrm{g} \mathrm{mL}^{-1}\right)$. Only dehydroascorbic acid produced a mild increase of $i$, which compared to the signal obtained for $100 \mu \mathrm{M} \mathrm{H}_{2} \mathrm{O}_{2}$ could be considered negligible (3.7\%, data not shown). It is important to point out that the present method has been developed for measuring $\mathrm{H}_{2} \mathrm{O}_{2}$ in extracellular media, without disruption of cell walls, so less interferences might be expected when using viable cell cultures.

To determine if the current signal obtained was only due to the presence of $\mathrm{H}_{2} \mathrm{O}_{2}$ in the media, catalase was added to the

Table 1. Values of the parameters from Eqns 3 and 4

\begin{tabular}{lc}
\hline Parameter & Value obtained \\
\hline$a_{0}$ & $6.31 \mathrm{~mA} \mathrm{~cm}^{-2}$ \\
$a_{1}$ & $-2.39 \mathrm{~mA} \mathrm{~cm}^{-2}$ \\
$a_{2}$ & $26.40 \mathrm{~mA} \mathrm{~cm}^{-2}$ \\
$b_{0}$ & $3.93 \mathrm{~mm}$ \\
$b_{1}$ & $7.35 \mathrm{~mm}$ \\
$b_{2}$ & 1.36 \\
\hline
\end{tabular}

cell cultures (Fig. 4). Plant suspension cultures treated with this enzyme (curve $b$ ) showed a current signal similar than that obtained for cell-free AT3 medium (curve $a$ ). Curve $c$ shows the current response of unstressed cells. These results suggest that any effect due to other chemical species in the extracellular medium was negligible and that $\mathrm{H}_{2} \mathrm{O}_{2}$ was the major species being detected. Thus, a quantitative determination of $\mathrm{H}_{2} \mathrm{O}_{2}$ could be performed.

\section{$\mathrm{H}_{2} \mathrm{O}_{2}$ concentration in unstressed cells}

The present method is able to measure a steady-state $\mathrm{H}_{2} \mathrm{O}_{2}$ concentration, being the overall result of the production and removal of this compound by different cell pathways. Thus, this electrode is useful for measuring real-time steady-state levels, which is very important. A continuous and quantitative measurement of $\mathrm{H}_{2} \mathrm{O}_{2}$ concentration in A. thaliana cell cultures (7-day-old, with a cell density of c. $3.4 \times 10^{6}$ cells per $\mathrm{mL}$ ) has been carried out here using calibration data previously determined for low $\mathrm{H}_{2} \mathrm{O}_{2}$ concentrations (Fig. 2). Firstly, the Pt sensor was used to evaluate the amount of extracellular $\mathrm{H}_{2} \mathrm{O}_{2}$ produced by plant cells without any stress stimuli. The results showed that all cellular suspensions under normal physiological conditions had $\mathrm{pH}$ in the range 5.5-5.7 and $\mathrm{H}_{2} \mathrm{O}_{2}$ concentrations in the range of 7.0-20.5 $\mu \mathrm{M}(n=5)$.

\section{Addition of exogenous $\mathrm{H}_{2} \mathrm{O}_{2}$ to plant cells}

It is known that plants are able to tolerate much higher intracellular $\mathrm{H}_{2} \mathrm{O}_{2}$ concentration than other organisms 


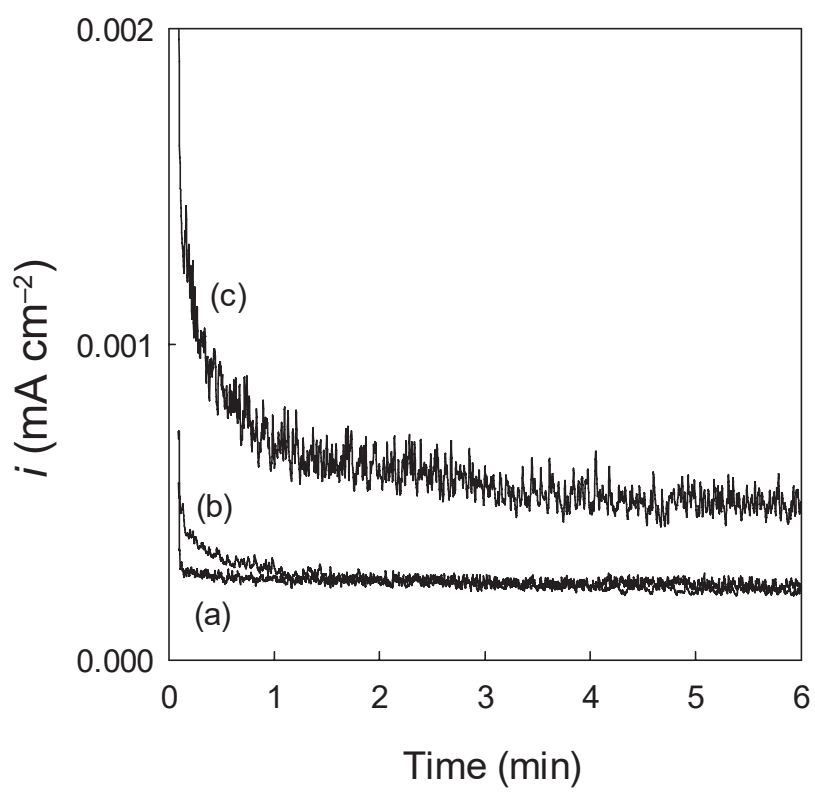

Figure 4. Effect of catalase on the current response of Arabidopsis thaliana cell cultures. Amperometric signal of: (a) cell-free AT3 medium, (b) Arabidopsis thaliana cell cultures 15 min after the incubation with $0.5 \mathrm{mg} \mathrm{mL}^{-1}$ catalase and (c) Arabidopsis thaliana cell cultures without any treatment.
(Queval et al. 2008). The scavenging of extracellular $\mathrm{H}_{2} \mathrm{O}_{2}$ is largely controlled by diffusion (Bienert, Schjoerring \& Jahn 2006). In addition, enzymes of the apoplast such as peroxidases and catalases protect the plasmalemma from oxidative damage by $\mathrm{H}_{2} \mathrm{O}_{2}$, decreasing its concentration. Plant cells have a remarkable ability to metabolize $\mathrm{H}_{2} \mathrm{O}_{2}$, and they can completely consume $\mathrm{H}_{2} \mathrm{O}_{2}$ concentrations as high as $10 \mathrm{~mm}$ in less than $10 \mathrm{~min}$ (Levine et al. 1994). However, it has also been reported that a $60 \mathrm{~min}$ exposure to $\left[\mathrm{H}_{2} \mathrm{O}_{2}\right] \geq 5 \mathrm{~mm}$ is sufficient to initiate an irreversible commitment to cell death in A. thaliana suspension cultures (Desikan et al. 1998).

A. thaliana cell suspensions were used to study the realtime behaviour of cells after $\mathrm{H}_{2} \mathrm{O}_{2}$ addition. To directly study the consumption of $\mathrm{H}_{2} \mathrm{O}_{2}$ by the cells, $2 \mathrm{~mm} \mathrm{H}_{2} \mathrm{O}_{2}$ was added to the $A$. thaliana cellular suspensions and current (at $+0.6 \mathrm{~V}$ versus $\mathrm{Ag} / \mathrm{AgCl}$ ) was monitored. Figure 5a shows the current response and the $\mathrm{H}_{2} \mathrm{O}_{2}$ concentration variation calculated using Eqn 5, following the addition of $\mathrm{H}_{2} \mathrm{O}_{2}$. The $\mathrm{pH}$ of the medium became progressively more alkaline (data not shown) in agreement with that previously reported (Bolwell et al. 2002). The initial bolus of $\mathrm{H}_{2} \mathrm{O}_{2}$ added was consumed in 7.7-9.8 $\min (n=3)$. This consumption of $\mathrm{H}_{2} \mathrm{O}_{2}$ was corroborated by cyclic voltammetric analysis of the plant cells before and after $\mathrm{H}_{2} \mathrm{O}_{2}$ addition (inset of Fig. 5a, solid and dashed line). As can be seen (inset of Fig 5a, dotted line), cells subjected to boiling showed no $\mathrm{H}_{2} \mathrm{O}_{2}$ consumption owing to enzyme denaturation.

Moreover, in cells that were previously incubated with catalase $\left(0.5 \mathrm{mg} \mathrm{mL}^{-1}\right.$, incubation time $\left.=15 \mathrm{~min}\right)$ the same
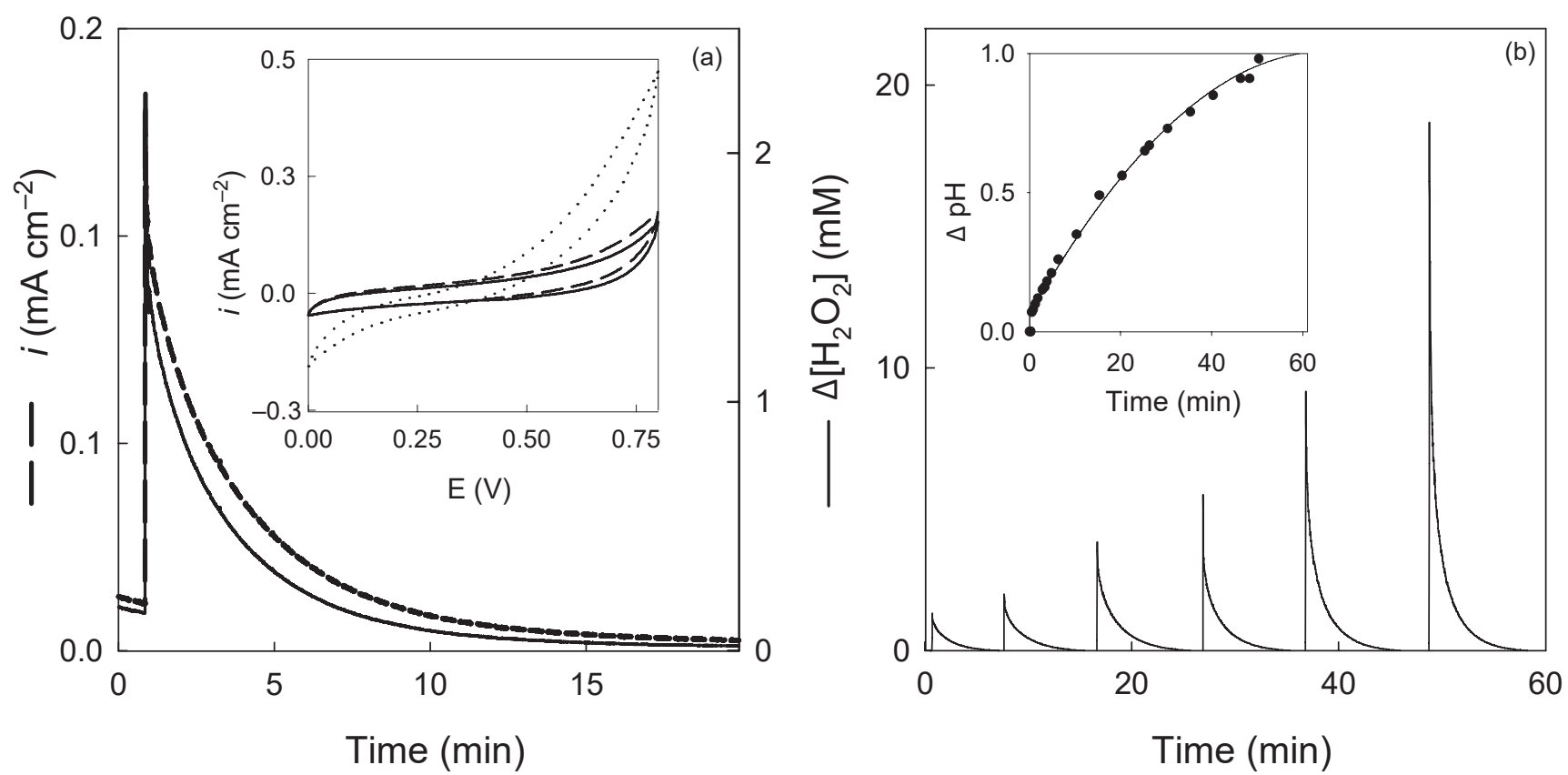

Figure 5. (a) Current intensity (dashed line) and $\left[\mathrm{H}_{2} \mathrm{O}_{2}\right]$ variation calculated using Eqn 5 (solid line) upon addition of $2 \mathrm{~mm} \mathrm{H}_{2} \mathrm{O}_{2}$ to Arabidopsis thaliana cells. Current intensity was measured using a potential of $+0.6 \mathrm{~V}$ versus $\mathrm{Ag} / \mathrm{AgCl}$ by amperometry. $\left[\mathrm{H}_{2} \mathrm{O}_{2}\right]$ was calculated according to Eqn 5. Inset: Cyclic voltammograms of cells without $\mathrm{H}_{2} \mathrm{O}_{2}$ exogenous addition (solid line), cells 20 min after the addition of $2 \mathrm{~mm} \mathrm{H}_{2} \mathrm{O}_{2}$ (dashed line) and boiled cells 20 min after the addition of $2 \mathrm{~mm} \mathrm{H}_{2} \mathrm{O}_{2}$ (dotted line). (b) $\mathrm{H}_{2} \mathrm{O}_{2}$ concentration calculated using Eqn 5 upon successive additions of $\mathrm{H}_{2} \mathrm{O}_{2}: 1,2,5,10,15$ and $20 \mathrm{~mm}$ (from left to right). Inset: $\mathrm{pH}$ variation of the extracellular medium during $\mathrm{H}_{2} \mathrm{O}_{2}$ additions. 
quantity of $\mathrm{H}_{2} \mathrm{O}_{2}(2 \mathrm{~mm})$ was depleted in less than $3 \mathrm{~min}$, whereas in the presence of the catalase inhibitor 3-amino1,2,4-triazole ( $2 \mathrm{~mm}$, incubation time $=12 \mathrm{~h}$, dark conditions $)$, $\mathrm{H}_{2} \mathrm{O}_{2}$ consumption took almost $3 \mathrm{~h}$ (data not shown). The $\mathrm{pH}$ increased in all cases.

In order to extend the study of cell behaviour with respect to $\mathrm{H}_{2} \mathrm{O}_{2}$ consumption, the ability of cell cultures to eliminate $\mathrm{H}_{2} \mathrm{O}_{2}$ upon successive additions was also evaluated (Fig. 5b). As can be seen, $\mathrm{H}_{2} \mathrm{O}_{2}$ depletion in cells was very rapid due to the significant ability of the antioxidant defence system of plant cellular metabolism to respond to elevated $\mathrm{H}_{2} \mathrm{O}_{2}$ levels. Even in the case of the addition of $20 \mathrm{mM} \mathrm{H}_{2} \mathrm{O}_{2}$, this was eliminated by the cells in less than $10 \mathrm{~min}$. The use of the bare Pt electrode allowed the effective monitoring of the $\mathrm{H}_{2} \mathrm{O}_{2}$ elimination by the cells in real time, without any sample treatment. The inset of Fig. $5 \mathrm{~b}$ shows the increase of the extracellular $\mathrm{pH}$ during successive $\mathrm{H}_{2} \mathrm{O}_{2}$ additions.

\section{Production of endogenous $\mathrm{H}_{2} \mathrm{O}_{2}$}

Hydrogen peroxide has also been shown to be an intercellular signal mediating systemic acquired resistance (Alvarez et al. 1998) and systemic acquired acclimation (Karpinski et al. 1999). Extracellular levels of $\mathrm{H}_{2} \mathrm{O}_{2}$ can increase during environmental stresses such as drought, excessive solar radiation, high temperature and in response to other exogenous factors (Miller et al. 2010). These factors include different environmental pollutants such as heavy metals, pesticides and salts, which are found in agricultural, urban and industrial wastes. A quantification of extracellular $\mathrm{H}_{2} \mathrm{O}_{2}$ production by cells during an oxidative burst could be very important. The performance of the sensor for the measurement of steady-state $\mathrm{H}_{2} \mathrm{O}_{2}$ produced by cells under different possible abiotic stresses was evaluated. For that purpose, several known chemical stimuli were assessed.

\section{Salt stress}

It is well known that NADPH oxidase homologues are activated under salt stress (Foreman et al. 2003; Ma et al. 2011) increasing the concentration of $\mathrm{O}_{2}^{\cdot-}$, whose spontaneous dismutation produces accumulation of $\mathrm{H}_{2} \mathrm{O}_{2}$. Both $\mathrm{O}_{2}^{--}$and excessive $\mathrm{H}_{2} \mathrm{O}_{2}$ production can damage cell macromolecules including lipids, proteins and nucleic acids (Halliwell \& Gutteridge 1986). The effect of salinity on the amount of $\mathrm{H}_{2} \mathrm{O}_{2}$ generated from $A$. thaliana cells can also be evaluated using the present electroanalytical method. Changes in the oxidative status were monitored by amperometry in real time. Figure 6 shows the results obtained when cells were exposed to $100 \mathrm{~mm}$ and $400 \mathrm{~mm} \mathrm{NaCl}$ (curves 3 and 4, respectively). In the absence of exogenous $\mathrm{NaCl}, \mathrm{H}_{2} \mathrm{O}_{2}$ levels remained relatively constant (curve 2). However, an increase of the current response was observed at about $2 \mathrm{~h}$ after the addition of the salt (curves 3 and 4). $\mathrm{pH}$ values were found to be 6.25 and 6.50 for cells exposed to $100 \mathrm{~mm}$ and $400 \mathrm{~mm} \mathrm{NaCl}$, respectively, in contrast to $\mathrm{pH} 5.5$ in unstressed cells. The increases in $\mathrm{H}_{2} \mathrm{O}_{2}$ concentration (calculated using sensitivity data from Fig. 2b) generated by the cells were 19.7 and $41.43 \mu \mathrm{M}$,

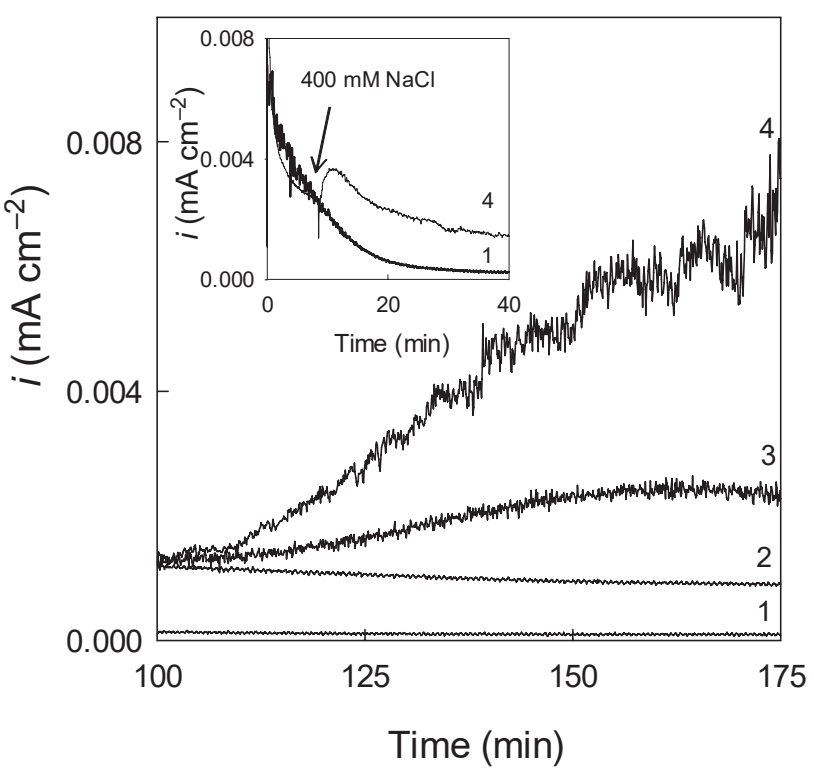

Figure 6. Effect of $\mathrm{NaCl}$ treatment on the current response in Arabidopsis thaliana after adding $0,100 \mathrm{~mm}$ and $400 \mathrm{~mm} \mathrm{NaCl}$ for curves 2, 3 and 4, respectively. $400 \mathrm{~mm} \mathrm{NaCl}$ was added to cell-free AT3 medium as a control, to assess the effect of the addition of $\mathrm{NaCl}$ on the electrochemical signal (curve 1). Inset: Addition of $400 \mathrm{~mm} \mathrm{NaCl}$ to AT3 medium (1) and cells (4) at short times.

respectively. The inset in Fig. 6 shows that the addition of $\mathrm{NaCl}$ also produced a small, but rapid increase in current intensity immediately upon addition of $\mathrm{NaCl}$ (curve 4), which was not observed in cell-free AT3 medium (curve 1), probably due to the immediate production of $\mathrm{H}_{2} \mathrm{O}_{2}$ by the cells after salt addition, which was subsequently reduced by their antioxidant defence system.

\section{Addition of metals}

The contamination of water, soil and sediments with toxic metals has been, and will continue to be a major environmental problem that needs to be dealt with. Exposure of plants to metals can result in oxidative stress as indicated by lipid peroxidation, $\mathrm{H}_{2} \mathrm{O}_{2}$ accumulation and an oxidative burst (Keunen et al. 2011). Based on their chemical and physical properties, different molecular mechanisms of heavy metal toxicity have been proposed (Schützendübel \& Polle 2001; Keunen et al. 2011).

The amperometric measurement of $\mathrm{H}_{2} \mathrm{O}_{2}$ was also used here to evaluate the dependence of $\mathrm{H}_{2} \mathrm{O}_{2}$ release from Arabidopsis thaliana cells upon addition of some toxic metals. The results obtained are summarized in Table 2 . The addition of different metals to AT3 medium in the absence of the cells did not produce any effect on the signal current (data not shown).

Data obtained showed that $\mathrm{Fe}^{2+}$ and $\mathrm{Cu}^{2+}$ initially (4.5 h) resulted in a decrease of $\mathrm{H}_{2} \mathrm{O}_{2}$ concentration, but in the case of $\mathrm{Fe}^{2+}$-exposed cells, rising after $24 \mathrm{~h}$. $\mathrm{Fe}^{2+}$ and $\mathrm{Cu}^{2+}$ have been shown to be significant in terms of oxidative stress as they undergo a Fenton reaction in the presence of $\mathrm{H}_{2} \mathrm{O}_{2}$. 


\begin{tabular}{|c|c|c|c|c|c|}
\hline \multirow[b]{2}{*}{ Chemical compound $^{a}$} & \multicolumn{2}{|c|}{$4.5 \mathrm{~h}$ after addition } & \multicolumn{2}{|c|}{$24 \mathrm{~h}$ after addition } & \multirow{2}{*}{$\begin{array}{l}\text { Total protein } \\
\text { ratio }(\%)^{\mathrm{b}}\end{array}$} \\
\hline & $\mathrm{pH}$ & $\Delta\left[\mathrm{H}_{2} \mathrm{O}_{2}\right](\mu \mathrm{M})$ & $\mathrm{pH}$ & $\Delta\left[\mathrm{H}_{2} \mathrm{O}_{2}\right](\mu \mathrm{M})$ & \\
\hline $\mathrm{CuSO}_{4}$ & 5.91 & -8.45 & 5.97 & -10.69 & 88 \\
\hline $\mathrm{FeSO}_{4}$ & 6.43 & -6.90 & 6.30 & +10.03 & 74 \\
\hline $\mathrm{ZnSO}_{4}$ & 5.45 & +5.46 & 5.33 & -0.41 & 100 \\
\hline $\mathrm{Al}\left(\mathrm{SO}_{4}\right)_{3}$ & 5.04 & +25.23 & 6.23 & +18.75 & 94 \\
\hline $\mathrm{CdSO}_{4}$ & 5.63 & +12.02 & 5.49 & +24.47 & 94 \\
\hline 3-amino-1,2,4-triazole & 5.53 & +3.81 & 5.33 & -3.03 & 82 \\
\hline Polygalacturonic acid & 5.62 & +6.78 & 5.45 & +6.48 & 97 \\
\hline Insecticide & 5.71 & -10.69 & 5.40 & -9.58 & 100 \\
\hline Fertilizer & 6.15 & -3.74 & 5.45 & +4.70 & 101 \\
\hline
\end{tabular}

Table 2. $\mathrm{H}_{2} \mathrm{O}_{2}$ concentrations in the medium of Arabidopsis thaliana cell suspensions after the addition of metals, an insecticide and a fertilizer

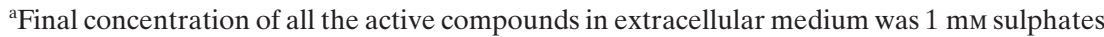
and 3-amino-1,2,4-triazole, $3 \mathrm{mg} \mathrm{L}^{-1}$ thiacloprid (insecticide) and polygalacturonic acid, and $0.21 \% \mathrm{~N}, 0.038 \% \mathrm{P}, 0.0285 \% \mathrm{~K}$ (fertilizer). Control cells (without any addition) had approximately $\mathrm{pH} 5.5$ and $\left[\mathrm{H}_{2} \mathrm{O}_{2}\right]=15 \mu \mathrm{M} . \mathrm{H}_{2} \mathrm{O}_{2}$ concentration variations, $\Delta\left[\mathrm{H}_{2} \mathrm{O}_{2}\right]$, were calculated as the difference between $\left[\mathrm{H}_{2} \mathrm{O}_{2}\right]$ after the addition of each component and $\left[\mathrm{H}_{2} \mathrm{O}_{2}\right]$ in control cells

${ }^{\mathrm{b}}$ Total protein ratio was calculated as the ratio between the total protein content after metal exposure and the total protein content in control cells.

Toxicity and cellular injury via this mechanism is well documented (Halliwell \& Gutteridge 1986; Winterbourn 1995). In this reaction, both hydroxyl radicals and higher oxidation states of metals are formed, which are capable of oxidizing a wide range of substrates and causing biological damage. Biological damage was evident as the colour of the cell suspensions changed from green to yellow-brown (data not shown). In addition, the $\mathrm{pH}$ became alkaline in both cases.

$\mathrm{Al}^{3+}, \mathrm{Zn}^{2+}$ and $\mathrm{Cd}^{2+}$ all gave rise to an increase in $\mathrm{H}_{2} \mathrm{O}_{2}$ production by the cells after $4.5 \mathrm{~h}$. In suspensions containing $\mathrm{Zn}^{2+}, \mathrm{H}_{2} \mathrm{O}_{2}$ gradually recovered to a new balance after $24 \mathrm{~h}$, which was attributed to the effect of ROS-scavenging defence system. This did not occur in the case of $\mathrm{Al}^{+3}$ and $\mathrm{Cd}^{2+}$ probably because the toxicity of these metals is higher and cellular homeostasis could not recuperate. Both of them are considered to be non-essential metals and generate toxic responses in organisms even at low-exposure concentrations (Keunen et al. 2011). In plants, it was suggested that $\mathrm{H}_{2} \mathrm{O}_{2}$ accumulation after $\mathrm{Cd}^{2+}$ exposure is produced because of depletion of cellular glutathione and inhibition of antioxidative enzymes (Schützendübel \& Polle 2001). Furthermore, recent studies have suggested that $\mathrm{Al}^{3+}$ induces programmed cell death in plants by means of ROS generation and a decrease of mitochondrial transmembrane potential caspase3-like activation (Li \& Xing 2011).

In addition, a decrease in A. thaliana cell growth was observed when cells were incubated with $\mathrm{Fe}^{2+}, \mathrm{Cu}^{2+}, \mathrm{Cd}^{2+}$ and also $\mathrm{Al}^{3+}$, as evidenced by the protein levels before and after exposure (Table 2, last column). Furthermore, after $24 \mathrm{~h}$, an increase of $\mathrm{pH}$ concomitant with the addition of $\mathrm{Fe}^{2+}, \mathrm{Cu}^{2+}$ and $\mathrm{Al}^{3+}$ was produced, whereas the addition of $\mathrm{Zn}^{2+}$ produced a decrease in $\mathrm{pH}$.

\section{Addition of other chemical stimuli}

Plant cell cultures were treated with other chemical stimuli including polygalacturonic acid, 3-amino-1,2,4-triazole, a commercial insecticide and a fertilizer. The $\mathrm{H}_{2} \mathrm{O}_{2}$ concentration produced by cells was also evaluated in each case. The addition of these compounds to cell-free AT3 medium did not produce any effect on the current signal (data not shown).

The presence of polygalacturonic acid produced an increase in $\mathrm{H}_{2} \mathrm{O}_{2}$ concentration and a mild increase of $\mathrm{pH}$ in the first $4.5 \mathrm{~h}$ (Table 2). A small decrease in cellular growth was also observed. In plants, polygalacturonic acids are major components of cell wall polysaccharides (pectins), which can be released into cells as a consequence of, e.g. pathogen colonization, giving rise to $\mathrm{H}_{2} \mathrm{O}_{2}$ and superoxide production (Legendre et al. 1993).

The presence of 3-amino-1,2,4-triazole led also to an increase of $\mathrm{H}_{2} \mathrm{O}_{2}$ concentration in the first $4.5 \mathrm{~h}$, which decreased during the next hours (Table 2). This is in agreement with data reported by May \& Leaver (1993), who showed a fourfold increase in the level of reduced glutathione in A. thaliana cells in the presence of 3-amino-1,2,4triazole, to combat the oxidative burst. However, cellular damage was also detected by us since the protein content decreased by about $18 \%$ with respect to control cells.

The addition of an insecticide containing thiacloprid as an active component decreased $\mathrm{H}_{2} \mathrm{O}_{2}$ production by cells (Table 2). This class of insecticides has been reported to enhance plant vigour and stress tolerance in some cases, independently of their insecticidal function (Ford et al. 2011).

The addition of a common fertilizer also caused a decrease in $\mathrm{H}_{2} \mathrm{O}_{2}$ concentration in the first hours, but this had increased $24 \mathrm{~h}$ after the addition. With respect to $\mathrm{pH}$ changes, an increase of $\mathrm{pH}$ was observed in both cases after the first $4.5 \mathrm{~h}$, which recovered $24 \mathrm{~h}$ after the addition.

\section{CONCLUDING REMARKS}

A bare Pt electrode was successfully applied to study the variation of $\mathrm{H}_{2} \mathrm{O}_{2}$ concentration in $A$. thaliana extracellular 
medium. Calibration plots at low $\mathrm{H}_{2} \mathrm{O}_{2}$ concentrations were linear with a maximum sensitivity at $\mathrm{pH}$ 6.0, whereas at higher $\mathrm{H}_{2} \mathrm{O}_{2}$ levels, the amperometric response was described by a hyperbolic equation and increased with $\mathrm{pH}$. Cell suspensions under normal physiological conditions had a $\mathrm{pH}$ between 5.5-5.7 and $\mathrm{H}_{2} \mathrm{O}_{2}$ concentrations in the range 7.0$20.5 \mu \mathrm{M}(n=5)$. To demonstrate how this methodology might be used the effects of the addition of $\mathrm{H}_{2} \mathrm{O}_{2}$, salt, toxic metals and other chemical treatments on A. thaliana cell cultures were evaluated, showing that changes in extracellular $\mathrm{H}_{2} \mathrm{O}_{2}$ production by these cells could be determined.

The protocol described here is a simple and reliable quantitative approach that has the potential to be used for realtime course analysis of $\mathrm{H}_{2} \mathrm{O}_{2}$ concentrations in plant cell suspensions. Pt electrochemical detection not only allows the real-time detection of $\mathrm{H}_{2} \mathrm{O}_{2}$ in biological systems, but also can help to study new insights about the role of $\mathrm{H}_{2} \mathrm{O}_{2}$ in plant physiological processes. This approach could be a first step in the development of future electrodes for in vivo monitoring of $\mathrm{H}_{2} \mathrm{O}_{2}$ in intact plants, especially in apoplastic fluids, and even in animals due to the existence of parallels between them. Furthermore, the method could also be extendable to micro-organisms and isolated organelles.

\section{ACKNOWLEDGMENTS}

This work has been supported by the Project POII10-02358597 from the Regional Ministry of Education and Science of Castilla-La Mancha (JCCM, Spain) and FP7/2007-2013 from EU (under Grant number 257372). M.I. González-Sánchez would like to thank University of West England (Centre for Research in Biosciences, Bristol, UK) for making possible the performance of this work and Marcus Pugh for his help with cell cultures preparation.

\section{REFERENCES}

Alvarez M.E., Pennell R.I., Meijer P.J., Ishikawa A., Dixon R.A. \& Lamb C. (1998) Reactive oxygen intermediates mediate a systemic signal network in the establishment of plant immunity. Cell 92, 773-784.

Amatore C., Arbault S., Bouton C., Drapier J.C., Ghandour H. \& Koh A.C.W. (2008) Real time amperometric analysis of reactive oxygen and nitrogen species released by single immunostimulated macrophages. ChemBioChem 9, 1472-1480.

Bienert G.P., Schjoerring J.K. \& Jahn T.P. (2006) Membrane transport of hydrogen peroxide. Biochimica et Biophysica Acta-Biomembranes 1758, 994-1003.

Bolwell G.P., Bindschedler L.V., Blee K.A., Butt V.S., Davies D.R., Gardner S.L., Gerrish C. \& Minibayeva F. (2002) The apoplastic oxidative burst in response to biotic stress in plants: a three-component system. Journal of Experimental Botany 53, 1367-1376.

Bradford M. (1976) A rapid and sensitive method for the quantitation of microgram quantities of protein utilizing the principle of dye-binding. Analytical Biochemistry 72, 248-254.

Cao D.X., Sun L.M., Wang G.L., Lv Y.Z. \& Zhang M.L. (2008) Kinetics of hydrogen peroxide electroreduction on Pd nanoparticles in acidic medium. Journal of Electroanalytical Chemistry 621, 31-37.

Clark A., Desikan R., Hurst R.D., Hancock J.T. \& Neill S.J. (2000) NO way back: nitric oxide and programmed cell death in Arabidopsis thaliana suspension cultures. Plant Journal 24, 667-677.

Dat J., Vandenabeele S., Vranová E., Van Montagu M., Inzé D. \& Breusegem V.F. (2000) Dual action of the reactive oxygen species during plant stress responses. Cellular and Molecular Life Sciences 57, 779-795.
Desikan R., Burnett E.C., Hancock J.T. \& Neill S.J. (1998) Harpin and hydrogen peroxide induce the expression of a homologue of gp91-phox in Arabidopsis thaliana. Journal of Experimental Botany 49, 1767-1771.

Flätgen G., Waste M., Eickes C., Radhakrishnan G., Doblhofer K. \& Ertl G. (1999) Autocatalytic mechanism of $\mathrm{H}_{2} \mathrm{O}_{2}$ reduction on Ag electrodes in acidic electrolyte: experiments and simulations. Journal of Electroanalytical Chemistry 44, 4499-4506.

Ford K.A., Gulevich A.G., Swenson T.L. \& Casida J.E. (2011) Neonicotinoid insecticides: oxidative stress in planta and metallo-oxidase inhibition. Journal of Agricultural and Food Chemistry 59, 4860-4867.

Foreman J., Demidchik V., Bothwell J.H.F., et al. (2003) Reactive oxygen species produced by NADPH oxidase regulate plant cell growth. Nature $\mathbf{4 2 2}$, 442-446.

Gay C., Collins J. \& Gebicki J.M. (1999) Hydroperoxidase assay with the ferric-xylenol orange complex. Analytical Biochemistry 273, 149-155.

González-Macia L., Smyth M.R., Morrin A. \& Killard A.J. (2011) Enhanced electrochemical reduction of hydrogen peroxide on silver paste modified with surfactant and salt. Electrochimica Acta 56, 4146-4153.

González-Sánchez M.I., Rubio-Retama J., López-Cabarcos E. \& Valero E. (2011a) Development of an acetaminophen amperometric biosensor based on peroxidase entrapped in polyacrylamide microgels. Biosensensors \& Bioelectronics 26, 1883-1889.

González-Sánchez M.I., García-Carmona F., Maciá H. \& Valero E. (2011b) Catalase-like activity of human methemoglobin: a kinetic and mechanistic study. Archives of Biochemistry and Biophysics 516, 10-20.

Guascito M.R., Filippo E., Malitesta C., Manno D., Serra A. \& Turco A. (2008) A new amperometric nanostructured sensor for the analytical determination of hydrogen peroxide. Biosensors \& Bioelectronics 24, 1057-1063.

Hall S.B., Khudaish E.A. \& Hart A.L. (1998) Electrochemical oxidation of hydrogen peroxide at platinum electrodes. Part I: an absorption-controlled mechanism. Electrochimica Acta 43, 579-588.

Halliwell B. \& Gutteridge J.M.C. (1986) Iron and free radical reactions: two aspects of antioxidant protection. Trends in Biochemical Sciences 11, 372375.

Hanaoka S., Lin J.M. \& Yamada M. (2001) Chemiluminiscent flow sensor for $\mathrm{H}_{2} \mathrm{O}_{2}$ catalyzed by cobalt(II)-ethanolamine complex immobilized on resin. Analytica Chimica Acta 426, 57-64.

Hurdis E.C. \& Romeyn H. (1954) Accuracy of determination of hydrogen peroxide by cerate oxidimetry. Analytical Chemistry 26, 320-325.

Karpinski S., Reynolds H., Karpinska B., Wingsle G., Creissen G. \& Mullineaus P. (1999) Systemic signaling and acclimation in response to excess excitation energy in Arabidopsis. Science 284, 654-657.

Keunen E., Remans T., Bohler S., Vangronsveld J. \& Cuypers A. (2011) Metalinduced oxidative stress and plant mitochondria. International Journal of Molecular Sciences 12, 6894-6918.

Legendre L., Rueter S., Heinstein P.F. \& Low P.S. (1993) Characterization of the oligogalacturonide-induced oxidative burst in cultured soybean cells. Plant Physiology 102, 233-240.

Levine A., Tenhaken R., Dixon R.A. \& Lamb C.J. (1994) $\mathrm{H}_{2} \mathrm{O}_{2}$ from the oxidative burst orchestrates the plant hypersensitive disease resistance response. Cell 79, 583-593.

Li Z. \& Xing D. (2011) Mechanistic study of mitochondria-dependent programmed cell death induced by aluminium phytotoxicity using fluorescence techniques. Journal of Experimental Botany 62, 331-343.

Ma L., Zhang H., Sun L., Jiao Y., Zhang G., Miao C. \& Hao F. (2011) NADPH oxidase AtrbohD and AtrbohF function in ROS-dependent regulation of $\mathrm{Na}^{+} / \mathrm{K}^{+}$homeostasis in Arabidopsis under salt stress. Journal of Experimental Botany 63, 305-317.

May J.M. \& Leaver C.J. (1993) Oxidative stimulation of glutathione synthesis in Arabidopsis thaliana suspension cultures. Plant Physiology 103, 621-627.

Miller G., Suzuki N., Ciftci-Yilmaz S. \& Mittler R. (2010) Reactive oxygen species homeostasis and signalling during drought and salinity stresses. Plant, Cell \& Environment 33, 453-467.

Mittler R., Vanderauwera S., Gollery M. \& Breusegem V. (2004) Reactive oxygen gene network of plants. Trends in Plant Science 9, 490-498.

Noctor G. \& Foyer C.H. (1998) Ascorbate and glutathione: keeping active oxygen under control. Annual Review of Plant Biology 49, 249-279.

Pignocchi C. \& Foyer C.H. (2003) Apoplastic ascorbate metabolism and its role in the regulation of cell signalling. Current Opinion in Plant Biology 6, 379-389.

Queval G., Hager J., Bertrand G. \& Noctor G. (2008) Why are literature data for $\mathrm{H}_{2} \mathrm{O}_{2}$ contents so variable? A discussion of potential difficulties in the 
quantitative assay of leaf extracts. Journal of Experimental Botany 59, 135 146.

Rhee S.G. (2006) $\mathrm{H}_{2} \mathrm{O}_{2}$, a necessary evil for cell signaling. Science 312, 1882 1883.

Rhee S.G., Chang T., Jeong W. \& Kang D. (2010) Methods for detection and measurement of hydrogen peroxide inside and outside of cells. Molecules and Cells 29, 539-549.

Schützendübel A. \& Polle A. (2001) Plant responses to abiotic stresses: heavy metal-induced oxidative stress and protection by mycorrhization. Journal of Experimental Botany 372, 1351-1365.

Valero E., González-Sánchez M.I., Maciá H. \& García-Carmona F. (2009) Computer simulation of the dynamic behavior of the glutathioneascorbate redox cycle in chloroplasts. Plant Physiology 149, 1958 1969.

Veljovic-Jovanonic S., Noctor G. \& Foyer C.H. (2002) Are leaf hydrogen peroxide concentrations commonly overestimated? The potential influence of artefactual interference by tissue phenolics and ascorbate. Plant Physiology and Biochemistry 40, 501-507.

Wei N., Xin X., Du J. \& Li J. (2011) A novel hydrogen peroxide biosensor based on the immobilization of hemoglobin on three-dimensionally ordered macroporous (3DOM) gold-nanoparticle-doped titanium dioxide (GTD) film. Biosensors \& Bioelectronics 26, 3602-3607.

Winterbourn C.C. (1995) Toxicity of iron and hydrogen peroxide: the Fenton reaction. Toxicology Letters 82, 969-974.

Wu P., Cai Z.W., Gao Y., Zhang H. \& Cai C.X. (2011a) Enhancing the electrochemical reduction of hydrogen peroxide based on nitrogen-doped graphene for measurement of its releasing process from living cells. Chemical Communications 47, 11327-11329.

Wu P., Cai Z.W., Chen J., Zhang H. \& Cai C.X. (2011b) Electrochemical measurement of the flux of hydrogen peroxide releasing from RAW 264.7 macrophage cells based on enzyme-attapulgite clay nanohybrids. Biosensensors \& Bioelectronics 26, 4012-4017.

Xu Q., Wei F., Wang Z., Yang Q., Zhao Y. \& Chen H. (2010) In vivo monitor oxidative burst induced by $\mathrm{Cd}^{2+}$ stress for the oilseed rape (Brassica napus L.) based on electrochemical microbiosensor. Phytochemical Analysis 21, 192-196.

Zhang Y. \& Wilson G.S. (1993) Electrochemical oxidation of $\mathrm{H}_{2} \mathrm{O}_{2}$ on Pt and $\mathrm{Pt}+\mathrm{Ir}$ electrodes in physiological buffer and its applicability to $\mathrm{H}_{2} \mathrm{O}_{2}$-based biosensors. Journal of Electroanalytical Chemistry 345, 253-271.

Received 28 March 2012; received in revised form 5 October 2012; accepted for publication 8 October 2012

\section{SUPPORTING INFORMATION}

Additional Supporting Information may be found in the online version of this article:

Evaluation of $\mathrm{H}_{2} \mathrm{O}_{2}$ content in extracellular media can be an important oxidative burst marker in plant cell cultures. This paper shows an electrochemical method based on a Pt-electrode which can be used for real-time course analysis of $\mathrm{H}_{2} \mathrm{O}_{2}$ concentrations in plant cell suspensions. The protocol has been satisfactory applied in Arabidopsis thaliana cell suspensions and could be a first step in the development of future electrodes for in vivo monitoring of $\mathrm{H}_{2} \mathrm{O}_{2}$. 